\title{
Effects of Supplementation with Increasing Levels of Energy Concentrate on the Productive Response and Ruminal Digestion of Dairy Cows Grazing Lucerne Pasture
}

\author{
Eloy Eduardo Salado ${ }^{*}$, Gustavo Bretschneider ${ }^{2}$, Alejandra Cuatrin1, \\ Gerardo Antonio Gagliostro ${ }^{3}$
}

\footnotetext{
${ }^{1}$ Area de Investigación en Producción Animal, Instituto Nacional de Tecnología Agropecuaria (INTA), Rafaela, Argentina

${ }^{2}$ Agencia de Extensión Rural Necochea, Instituto Nacional de Tecnología Agropecuaria (INTA), Necochea, Argentin

${ }^{3}$ Area de Investigación en Producción Animal, Instituto Nacional de Tecnología Agropecuaria (INTA), Balcarce, Argentina

Email: *salado.eloy@inta.gob.ar
}

How to cite this paper: Salado, E.E., Bretschneider, G., Cuatrin, A. and Gagliostro, G.A. (2018) Effects of Supplementation with Increasing Levels of Energy Concentrate on the Productive Response and $\mathrm{Ru}$ minal Digestion of Dairy Cows Grazing Lucerne Pasture. Agricultural Sciences, 9, 1487-1505.

https://doi.org/10.4236/as.2018.911104

Received: November 3, 2018

Accepted: November 27, 2018

Published: November 30, 2018

Copyright $\odot 2018$ by authors and Scientific Research Publishing Inc. This work is licensed under the Creative Commons Attribution International License (CC BY 4.0).

http://creativecommons.org/licenses/by/4.0/

\begin{abstract}
The aim of the study was to determine the effect of three levels of energy concentrate intake on dry matter (DM) and energy intake, milk yield and composition, rumen environment and pasture neutral detergent fiber (NDF) digestion. Twelve Holstein multiparous cows in early lactation (69.0 \pm 5 days postpartum) producing $32.8( \pm 4.0) \mathrm{kg}$ milk were assigned to three treatments at (kg/cow day) 3.5 (T3.5), 7.0 (T7.0) and 10.5 (T10.5) kg concentrate in a $3 \times$ 3 Latin Square design. Parameters of ruminal environment and neutral detergent fiber (NDF) digestion were obtained using 3 additional rumen cannulated cows. Concentrate was composed (as fed) by corn grain (68\%), soybean meal $(22 \%)$, wheat bran $(8 \%)$ and a vitamin-mineral premix including monensin and thoroughly consumed. Yields $\left(\mathrm{kg} / \mathrm{cow}\right.$ day $\left.^{-1}\right)$ of milk, $4 \%$ fat corrected milk (4\% FCM 4\%) and energy corrected milk (ECM) resulted higher $(p<0.05)$ in T7.0 $(29.6,26.1$ and 25.7$)$ compared to T3.5 $(27.7,24.5$ and 24.2) but similar to those obtained in T10.5 (30.6, 26.2 and 26.0). Milk protein yield increased linearly $(p<0.01)$ from 0.82 to $0.92 \mathrm{~kg} / \mathrm{cow}$ day ${ }^{-1}$ without effects on yield of milk fat. Concentrations ( $\mathrm{g} / 100 \mathrm{~g}$ ) of milk fat (3.19), protein (2.97), total solids (11.75), non-fat solids (8.60) and casein (2.40) did not differ. Milk lactose content $(\mathrm{g} / 100 \mathrm{~g})$ was linearly increased $(p$ $<0.02$ ) from 4.91 to 4.98 whereas milk urea decreased $(p<0.01)$ from 0.048 to 0.043 . Intakes of DM and energy increased with concentrate level without effects on conversion efficiency. Changes in live weight (LW), body condition score (BCS) and concentrations of plasma non-esterified fatty acids (NEFA),
\end{abstract}


glucose, insulin, somatotrophin $(\mathrm{GH})$ and insulin-like growth factor (IGF-I) were not affected. Plasma urea levels resulted lower $(p<0.05)$ in T10.5. Ruminal $\mathrm{pH}$ and ammonia nitrogen $\left(\mathrm{N}-\mathrm{NH}_{3}\right)$ resulted lower $(p<0.05)$ in T10.5 compared to T3.5. Concentration of total volatile fatty acids (VFA) was higher $(p<0.05)$ in T3.5 due to the increase in acetate and butyrate while the ace-

tate: Propionate ratio remained unchanged. Pasture NDF digestion was affected as concentrate intake increased. To increase milk protein yield and reduce concentrations of $\mathrm{N}-\mathrm{NH}_{3}$ in rumen and milk, feeding an energy concentrate at $41 \%$ of total DM intake resulted an effective tool.

\section{Keywords}

Dairy Cows, Concentrate, Milk Yield, Ruminal Digestion

\section{Introduction}

In dairy systems feeding costs quadratically decrease as the contribution of pasture in the total diet increases [1] but its energy density is insufficient to meet total energy requirements to attain the maximum milk yield in high yielding dairy cows [2]. A lower DM and energy intakes in pasture based systems explain the suboptimal milk production even when herbage allowance and pasture quality are not limiting [3]. When high quality spring pastures are the sole feeding source, maximum milk yield is expected to be around $23.2 \mathrm{~kg} / \mathrm{cow} \mathrm{day}^{-1}$ [4] and higher yields would be achieved if the BCS of cows allows energy mobilization but excessive lipid mobilization may induce metabolic and reproductive disorders [5]. Supplementation with energy concentrates may improve the productive response of cows [6] reducing the loss of body reserves [7]. Milk production in pasture based systems may be also limited by imbalances at ruminal level between availability of fermentable energy and the excess of rumen degradable protein (RDP) as suggested by [8]. Pasture RDP utilization can be improved by feeding starch-rich concentrates [9] but when high levels of cereal-based supplements are fed, ruminal $\mathrm{pH}$ and pasture NDF digestion can be affected [10] leading to reductions in forage intake and milk fat content. The aim of this study was to determine the effect of feeding three levels of energy concentrate on milk yield and composition, DM and energy intake, plasma metabolite and hormone concentrations and ruminal pasture NDF digestion in grazing dairy cows.

\section{Materials and Methods}

\subsection{Cows and Treatments}

The experiment was carried out at the experimental farm of INTA Rafaela $\left(31^{\circ} 12^{\prime} \mathrm{S}, 61^{\circ} 30^{\prime} \mathrm{W}\right)$ during spring time of 2008 . Twelve multiparous $(3.2 \pm 1.3$ lactations) Holstein cows in early lactation (69.2 \pm 5 days in milk) were used to measure milk production and composition, BW, BCS, DM intake (DMI) and 
plasma metabolite and hormone concentration. At the start of the experiment, cows were producing $32.8( \pm 4.0) \mathrm{kg}$ milk, averaging $623.5( \pm 44.0) \mathrm{kg} \mathrm{BW}$ and $2.52( \pm 0.21)$ BCS. Cows were grouped by milk production, number of lactations and days postpartum and randomly assigned to one of three treatments (4 cows/treatment) in a Latin Square design with 3 experimental periods of 19 days (d) with the first $14 \mathrm{~d}$ for adaptation and the last $5 \mathrm{~d}$ for data collection. Parameters of ruminal environment and NDF digestion were obtained using 3 additional cows of the same breed fitted with rumen cannulae in a Latin Square with experimental periods of $19 \mathrm{~d}$ ( $17 \mathrm{~d}$ for adaptation and $2 \mathrm{~d}$ for measurements). All cows were fitted with transponders (ALPRO version 6.60/DeLaval, Tumba, Sweden) to individually record daily yield of milk and concentrate allocation at the milking parlor according to treatments consisting in three levels of energy concentrate at 3.5 (T3.5), 7.0 (T7.0) and 10.5 (T10.5) kg cow day ${ }^{-1}$. On a wet basis, concentrate was composed by corn grain $(68 \%)$, soybean meal (22\%), wheat bran (8\%) and a vitamin-mineral nucleus including monensin. The daily amount of concentrate was supplied by halves in individual feeders during each milking time at 4:30 a.m. and 3:30 p.m. giving enough time to the cows to consume all of it. An alfalfa (Medicago sativa, sp) pasture was used in a rotational grazing system adjusting herbage allowance at $30 \mathrm{~kg} \mathrm{DM} / \mathrm{cow} \mathrm{d}^{-1}$ using a portable electric wiring. During the 3 weeks prior to the start of the trial all cows received $7.0 \mathrm{~kg}$ of concentrate and pasture.

\subsection{Samples Collection and Analysis}

Herbage mass $\left(\mathrm{kg} \mathrm{DM} \mathrm{ha}^{-1}\right)$ was weekly measured by samples cutted at $4 \mathrm{~cm}$ height with manual scissors in an area delimited by a metal frame of $0.125 \mathrm{~m}^{2}$, cutting a total area of $1 \mathrm{~m}^{2}$ in each sample. The sample composed of 8 subsamples of $0.125 \mathrm{~m}^{2}$ was dried in an oven at $65^{\circ} \mathrm{C}$ for 48 hours to determine DM content. Based on this measure, the area of the daily strips was established ensuring the target herbage allowance. During the last 5 days of each experimental period, daily and samples of concentrate and pasture were obtained. Pasture samples were taken manually in the grazing horizon simulating the selectivity of the cow by hand-plucking [11]. All samples were dried $\left(65^{\circ} \mathrm{C}\right.$ for $\left.48 \mathrm{~h}\right)$ and ground through a 1-mm screen (Wiley mill, Philadelphia, PA). Two representative composite samples from each experimental period were analyzed for NDF content [12], acid detergent fiber (ADF, [13], \# 973.18), ether extract (EE; [14], \# 920.39), acid detergent lignin (LDA; [13], \# 973.18), total nitrogen (Kjeldhal method 976.05 of [14]), crude protein (CP, total nitrogen $\times 6.25)$, ash ([13] \# 942.05) and in vitro DM digestibility (IVDMD) according to [15]. Concentrate samples were also analyzed for starch content [16].

In 2 of the 5 days corresponding to the data collection of each experimental period, milk samples were collected during each milking time using milk meters (DeLaval International AB, Tumba, Sweden) to make a single individual sample (pool) per day weighted by the respective individual milk production. In each 
composite sample, concentration of milk fat, total protein, lactose, total solids (TS), non-fat solids (NFS) and urea was determined by infrared spectrophotometry (MilkoScanTM Minor, FOSS Electric, Hillerod, Denmark) according to the ISO standard method/IDF (ISO 9622 IDF 141, 2013). Milk casein content was calculated as $6.38 *$ (total $\mathrm{N}$-non caseinic N) after semi Micro-Kjeldhal digestion and colorimetric reading in Technicon continuous flow autoanalyzer according to [17]. Fat-corrected milk (4\% FCM) was adjusted according to [18] and energy-corrected milk (ECM) as proposed by [18]. The cows were weighed individually with an electronic balance at the beginning and end of each experimental period after the morning milking and preventing access to water. Along with this procedure, BCS was determined by two independent observers using a scale of 5 points $(1=$ excessively thin and $5=$ excessively fat $)$ with increments of 0.25 [20] taking into account the average result of both evaluators.

On the last day of each experimental period and after the 4:30 a.m. milking blood samples were taken by coccygeal vein puncture. The blood was collected in tubes containing sodium heparin $(5 \mathrm{U} / \mathrm{ml})$ and plasma was obtained by centrifugation $\left(2000 \times \mathrm{g}\right.$ for $15 \mathrm{~min}$ at $\left.4^{\circ} \mathrm{C}\right)$ and stored at $-24^{\circ} \mathrm{C}$ until analized for glucose (Enzymatic blood glucose, Wiener Laboratory, Rosario, Argentina), urea (Uremia, Wiener Laboratory, Rosario, Argentina ), non-esterified fatty acids (NEFA) (NEFA, Randox Laboratories Ltd., UK), insulin, growth hormone (GH) and insulin-like growth factor (IGF-I) as described in [21].

Intake of concentrate was daily and individually recorded by the difference between the quantity offered and refused throughout the trial. Pasture intake was estimated in each experimental period from the production of feces of each animal and from the IVDMD of the pasture as decribed in [22]. Intake of net energy for lactation $\left(\mathrm{NE}_{\mathrm{L}}\right)$ was calculated based on the equations from [23] and glucogenic energy (GE) according to [24] assuming an intestinal starch digestibility of a $78 \%[25]$.

\subsection{Rumen Environment and In Situ Pasture NDF Degradability}

The rate and extent of pasture NDF degradation was estimated using the in situ technique [26]. At the start of the incubation period, two bags containing $5 \mathrm{~g}$ $\mathrm{DM}$ of pasture per sampling hour were introduced into the ventral sac of the rumen of the fistulated cows. The bags were extracted by duplicate for the different hours of incubation $(0,4,8,12,16,20,24,36$ and 48 hours) and frozen $\left(-24^{\circ} \mathrm{C}\right)$ until the end of each period. Afterwards, they were thawed and externally washed under a cold water stream to remove contaminating and soluble material. Then all the bags were washed in a washing machine, dried in a forced air oven $\left(60^{\circ} \mathrm{C}\right.$ for 48 hours) and weighed to determine the residual DM and NDF contents. Kinetics parameters of NDF degradation were estimated with the equation proposed by [27] using the Excel solver routine [28] as described in [22]. During the first six sampling hours, $200 \mathrm{~mL}$ of ruminal liquor from the ventral sac were drawn from each cannulated cow for measurements of $\mathrm{pH}$, ammonia nitrogen $\left(\mathrm{NH}_{3}-\mathrm{N}\right)$ and volatile fatty acid (VFA). Immediately after ex- 
traction and previous filtration of the ruminal liquor with cheese-like cloth, $\mathrm{pH}$ was measured with a portable digital $\mathrm{pH}$-meter (ORION model $250 \mathrm{~A}$ ). A sample $(100 \mathrm{~mL})$ was acidified with $1 \mathrm{~mL}$ of $1 \mathrm{~N} \mathrm{H}_{2} \mathrm{SO}_{4}$ and stored at $-20^{\circ} \mathrm{C}$ until the $\mathrm{NH}_{3}-\mathrm{N}$ and VFA determinations. The $\mathrm{NH}_{3}-\mathrm{N}$ concentration was determined by titration with steam entrainment prior to alkalization of the samples with sodium hydroxide according to [29]. For VFA determination, the samples were purified with orthophosphoric acid (25\%) on sulfuric acid $0.5 \mathrm{M}$ at $0.5 \mathrm{~mL}$ for each $2 \mathrm{~mL}$ of sample and then centrifuged per $10 \mathrm{~min}$ with $5000 \mathrm{~g}$ as described in [30]. Samples were injected by auto-sampler Robokrom ${ }^{\circledR}$ GC on a Konik GC 5000 B equipped with a flame ionization detector. VFA (injected using a 10:1 split ratio and splitless time 9) were separated on a Nukol capillary column (30 $\mathrm{m} \times 0.32 \mathrm{~mm}$ i.d. $\times 0.25 \mu \mathrm{m}$ film thickness; Perkin Elmer - Elite FFAP; Part. N9316354). The FID injector temperature was held at $250^{\circ} \mathrm{C}$, and the detector temperature at $250^{\circ} \mathrm{C}$. The initial oven temperature was $80^{\circ} \mathrm{C}$ (held for $1 \mathrm{~min}$ ), which was then increased to $156^{\circ} \mathrm{C}$ at a rate of $9^{\circ} \mathrm{C} / \mathrm{min}$ (held for $0 \mathrm{~min}$ ). Hydrogen was used as a carrier gas and column flow was held at $2.4 \mathrm{~mL} / \mathrm{min}$. It was used for the calibration curves the standard volatile acid mix Supelco (Cat. No. 46975-U).

\subsection{Statistical Analysis}

Milk production and composition (mean values from the last five days of each experimental period), changes in BW and BCS, DM intake, metabolite and hormone concentration and kinetic parameters of ruminal NDF digestion were analyzed according to a Latin Square design (3 treatments and 3 experimental periods) using the MIXED procedure of SAS [31]. The model used was:

$$
Y_{i j k l}=\mu+T_{i}+P_{j}+S_{k}+A_{(k) l}+E_{i j k l}
$$

where $Y_{i j k l}=$ dependent variable; $\mu=$ overall mean; $T_{i}=$ treatment effects; $P_{j}=$ effects of the experimental period; $S_{k}=$ effects of the sequence; $A_{(k) l}=$ random effects of animal within sequence and $E_{i j k l}=$ residual error. The rumen parameters $\left(\mathrm{pH}, \mathrm{NH}_{3}-\mathrm{N}\right.$ and VFA) were analyzed in a $3 \times 3$ Latin Square design using the following model:

$$
Y_{i j k l m}=\mu+T_{i}+P_{j}+S_{k}+A_{(k) l}+H_{m}+E_{i j k l}
$$

where $Y_{i j k l m}=$ dependent variable; $\mu=$ overall mean; $T_{i}=$ treatment effects; $P_{j}=$ effects of the experimental period; $S_{k}=$ effects of the sequence; $\mathrm{A}_{(\mathrm{k}) 1}=$ random effects of animal within sequence, $H_{m}=$ effects of hour of sampling; $T \times H_{i m}=$ interaction effects of treatment and hour and $E_{i j k l m}=$ residual error. Mean comparisons were carried out using the Tukey-Kramer test, and differences were considered significant with $p<0.05$. Linear and/or quadratic effects of concentrate levels were also tested by orthogonal contrasts.

\section{Results}

\subsection{Chemical Composition of Feedstuffs}

Chemical composition of feedstuffs are shown in Table 1. Herbage mass in the 
Table 1. Chemical composition of pasture and concentrate ${ }^{1}$.

\begin{tabular}{ccc}
\hline Parameters & Pasture $^{2}$ & Concentrate \\
\hline DM (\%) & $20.3 \pm 1.3$ & $90.7 \pm 1.4$ \\
OM & $89.8 \pm 0.9$ & $\mathrm{~g} / 100 \mathrm{~g} \mathrm{DM}$ \\
IVDMD & $69.6 \pm 2.2$ & $93.8 \pm 0.8$ \\
CP & $23.9 \pm 1.3$ & $84.1 \pm 1.2$ \\
NDF & $41.5 \pm 3.6$ & $18.0 \pm 1.3$ \\
ADF & $25.7 \pm 3.6$ & $17.0 \pm 1.9$ \\
ADL & $5.5 \pm 0.4$ & $6.1 \pm 1.1$ \\
EE & $2.5 \pm 0.3$ & $0.9 \pm 0.4$ \\
Starch & $\mathrm{Nd}$ & $4.5 \pm 0.7$ \\
\hline
\end{tabular}

${ }^{1}$ Values are expressed through the mean \pm standard deviation. ${ }^{2}$ Perennial pastures of alfalfa (Medicago sativa). $\mathrm{DM}=$ dry matter; $\mathrm{OM}=$ organic matter; $\mathrm{IVDMD}=$ in vitro $\mathrm{DM}$ digestibility; $\mathrm{CP}=$ crude protein; $\mathrm{NDF}$ $=$ neutral detergent fiber; $\mathrm{ADF}=$ acid detergent fiber; $\mathrm{ADL}=$ acid detergent lignin; $\mathrm{EE}=$ ether extract; $\mathrm{nd}=$ not determined.

pregrazing strips averaged $2033( \pm 131) \mathrm{kg} \mathrm{DM} \mathrm{ha}^{-1}$ with an herbage allowance of $30.6( \pm 1.2) \mathrm{kg} \mathrm{DM} \mathrm{cow}^{-1}$ day $^{-1}$ during the trial.

Pasture contents of $\mathrm{CP}, \mathrm{NDF}, \mathrm{ADF}, \mathrm{ADL}$ and ash were consistent to the average values for spring alfalfa pastures while contents of DM and EE were located in the lower limit of the ranges informed in [32] for this type of pastures (20\% to $27 \%$ and $2.0 \%$ to $6.0 \%$ for DM and EE, respectively).

\subsection{Milk Production and Composition}

Yields of milk, 4\% FCM and ECM in T7.0 were significantly higher $(p<0.05)$ compared to T3.5 and similar to that obtained in T10.5 while protein production increased $(p<0.01)$ with the level of supplementation $(50 \mathrm{~g} /$ day $)$ without significant differences in milk fat output (Table 2).

Milk concentrations of fat, protein, ST, SNG and casein were similar between treatments. Lactose content resulted higher in T10.5 compared to T3.5 while milk urea content was lower in T10.5. These results suggest a greater glucose availability to the mammary gland and a better protein-energy balance in the rumen respectively. This last statement is compatible with the lower values of $\mathrm{NH}_{3}-\mathrm{N}$ in the rumen observed in T10.5 treatment (see later). The contrasts also revealed linear increases for milk lactose content, yields of milk, 4\% FCM, MCE and protein with linear decrements for milk urea content when concentrate intake increased. No quadratic effects were detected for any of the analyzed variables.

\subsection{Dry Matter and Energy Intake}

Concentrate was thoroughly consumed by cows and no refusals were observed in any treatment. The estimated pasture DM intake resulted higher in T3.5, without differences between T7.0 and T10.5 (Table 3). Pasture substitution rate 
Table 2. Milk production and composition in grazing dairy cows supplemented with an energy concentrate at $3.5(\mathrm{~T} 3.5), 7.0(\mathrm{~T} 7.0)$ or $10.5(\mathrm{~T} 10.5) \mathrm{kg} \cdot \mathrm{d}^{-1}$.

\begin{tabular}{|c|c|c|c|c|c|c|c|}
\hline \multirow{2}{*}{ Variable } & \multicolumn{3}{|c|}{ Treatment $^{1}$} & \multirow{2}{*}{ SEM } & \multicolumn{3}{|c|}{$p<$} \\
\hline & T3.5 & T7.0 & $\mathrm{T} 10.5$ & & Treat $^{2}$ & Lineal $^{3}$ & Quadratic $^{3}$ \\
\hline Milk, kg cow ${ }^{-1} \mathrm{~d}^{-1}$ & $27.7^{\mathrm{b}}$ & $29.6^{\mathrm{a}}$ & $30.6^{\mathrm{a}}$ & 0.91 & 0.01 & 0.01 & 0.36 \\
\hline $4 \%$ FCM. kg cow ${ }^{-1} \mathrm{~d}^{-1}$ & $24.5^{\mathrm{b}}$ & $26.1^{\mathrm{a}}$ & $26.2^{\mathrm{a}}$ & 0.62 & 0.01 & 0.01 & 0.11 \\
\hline $\mathrm{ECM}, \mathrm{kg} \mathrm{cow}^{-1} \mathrm{~d}^{-1}$ & $24.2^{\mathrm{b}}$ & $25.7^{\mathrm{a}}$ & $26.0^{\mathrm{a}}$ & 0.62 & 0.01 & 0.01 & 0.18 \\
\hline \multicolumn{8}{|l|}{ Milk fat } \\
\hline $\mathrm{kg} \operatorname{cow}^{-1} \mathrm{~d}^{-1}$ & 0.90 & 0.95 & 0.93 & 0.03 & 0.23 & 0.30 & 0.15 \\
\hline$g / 100 g$ & 3.26 & 3.25 & 3.05 & 0.11 & 0,14 & 0,08 & 0,33 \\
\hline \multicolumn{8}{|l|}{ Milk protein } \\
\hline $\mathrm{kg} \operatorname{cow}^{-1} \mathrm{~d}^{-1}$ & $0.82^{\mathrm{c}}$ & $0.87^{\mathrm{b}}$ & $0.92^{\mathrm{a}}$ & 0.03 & 0.01 & 0.01 & 0.86 \\
\hline $\mathrm{g} / 100 \mathrm{~g}$ & 2.97 & 2.95 & 2.99 & 0.05 & 0.56 & 0.63 & 0.35 \\
\hline Lactose, $\mathrm{g} / 100 \mathrm{~g}$ & $4.91^{\mathrm{b}}$ & $4.93^{\mathrm{ab}}$ & $4.98^{\mathrm{a}}$ & 0.02 & 0.04 & 0.02 & 0.55 \\
\hline $\mathrm{ST}, \mathrm{g} / 100 \mathrm{~g}$ & 11.79 & 11.78 & 11.67 & 0.15 & 0.65 & 0.40 & 0.66 \\
\hline SNG, $g / 100 \mathrm{~g}$ & 8.57 & 8.57 & 8.66 & 0.06 & 0.27 & 0.15 & 0.43 \\
\hline Urea, g/100g & $0.048^{\mathrm{a}}$ & $0.047^{\mathrm{a}}$ & $0.043^{b}$ & 0.001 & 0.01 & 0.01 & 0.17 \\
\hline Casein, $\mathrm{g} / 100 \mathrm{~g}$ & 2.40 & 2.38 & 2.42 & 0.02 & 0.21 & 0.42 & 0.12 \\
\hline
\end{tabular}

${ }^{1}$ Values are expressed as least square means (LS Means) and standard error of LS Means (SEM). ${ }^{2}$ Effect of treatment (Treat). ${ }^{3}$ Contrast. ${ }^{\mathrm{a}, \mathrm{b}, \mathrm{c}} \mathrm{W}$ ithin rows LS Means with different letters differs (Tukey-Kramer test, $p<$ 0.05). $4 \% \mathrm{FCM}=4 \%$ fat corrected milk; $\mathrm{ECM}=$ energy corrected milk; $\mathrm{TS}=$ total solids; $\mathrm{NFS}=$ non-fat solids.

Table 3. Dry matter and energy intakes in grazing dairy cows supplemented with an energy concentrate at 3.5 (T3.5), 7.0 (T7.0) and $10.5(\mathrm{~T} 10.5) \mathrm{kg} \cdot \mathrm{d}^{-1}$.

\begin{tabular}{|c|c|c|c|c|c|c|}
\hline \multirow{2}{*}{ Variable } & \multicolumn{3}{|c|}{ Treatment $^{1}$} & \multirow{2}{*}{ SEM } & \multicolumn{2}{|c|}{$p<^{2}$} \\
\hline & T3.5 & T7.0 & T10.5 & & Treat. & Period \\
\hline \multicolumn{7}{|l|}{ Pasture intake } \\
\hline $\mathrm{DM}, \mathrm{kg} \cdot \mathrm{d}^{-1}$ & $17.42^{\mathrm{a}}$ & $14.59^{\mathrm{b}}$ & $13.85^{\mathrm{b}}$ & 0.54 & 0.01 & 0.04 \\
\hline $\mathrm{NE}_{\mathrm{L}}, \mathrm{Mcal} \cdot \mathrm{d}^{-1}$ & $24.92^{\mathrm{a}}$ & $20.87^{\mathrm{b}}$ & $19.80^{\mathrm{b}}$ & 0.77 & 0.01 & 0.04 \\
\hline \multicolumn{7}{|l|}{ Total intake } \\
\hline $\mathrm{DM}, \mathrm{kg} \cdot \mathrm{d}^{-1}$ & $20.60^{\mathrm{b}}$ & $20.94^{\mathrm{b}}$ & $23.37^{\mathrm{a}}$ & 0.54 & 0.01 & 0.04 \\
\hline $\mathrm{NE}_{\mathrm{L}}^{3}, \mathrm{Mcal} \cdot \mathrm{d}^{-1}$ & $31.43^{\mathrm{c}}$ & $33.88^{\mathrm{b}}$ & $39.33^{\mathrm{a}}$ & 0.77 & 0.01 & 0.04 \\
\hline $\mathrm{GE}^{4}, \mathrm{Mcal} \mathrm{EN} \mathrm{L}_{\mathrm{L}} \mathrm{d}^{-1}$ & $7.96^{c}$ & $8.98^{\mathrm{b}}$ & $9.67^{\mathrm{a}}$ & 0.18 & 0.01 & 0.04 \\
\hline \multicolumn{7}{|l|}{ Conversion efficiency } \\
\hline Milk kg·MS ${ }^{-1}$ & 1.36 & 1.43 & 1.32 & 0.06 & 0.16 & 0.01 \\
\hline Milk Mcal EN ${ }_{\mathrm{L}}^{-1}$ & $0.89^{\mathrm{a}}$ & $0.88^{\mathrm{a}}$ & $0.78^{\mathrm{b}}$ & 0.04 & 0.01 & 0.01 \\
\hline $\mathrm{ECM} \mathrm{kg} \cdot \mathrm{MS}^{-1}$ & 1.18 & 1.24 & 1.12 & 0.04 & 0.09 & 0.01 \\
\hline ECM Mcal EN ${ }_{\mathrm{L}}^{-1}$ & $0.78^{\mathrm{a}}$ & $0.76^{\mathrm{a}}$ & $0.67^{\mathrm{b}}$ & 0.03 & 0.01 & 0.01 \\
\hline
\end{tabular}

${ }^{1}$ Values are expressed as least square means (LSMeans) and standard error of LSMeans (SEM). ${ }^{2}$ Effects of treatment (Treat) and period. ${ }^{3}$ Calculated using [23]. $\mathrm{NE}_{\mathrm{L}}$ values for the pasture and concentrate: 1.43 and $2.05 \mathrm{Mcal} \mathrm{kg} \mathrm{DM}^{-1}$ respectively. ${ }^{4}$ Energy provided by glucogenic precursors available from the rumen and

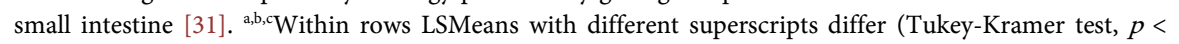
0.05). $\mathrm{NE}_{\mathrm{L}}=$ net energy for lactation; $\mathrm{GE}$ = glucogenic energy; $\mathrm{ECM}=$ energy corrected milk. 
(kg DM pasture/kg MS concentrate) was 0.88 between T3.5 and T7.0 and 0.23 between T7.0 and T10.5.

The total DM intake was higher in T10.5 without differences between T3.5 and T7.0 while total $\mathrm{NE}_{\mathrm{L}}$ intake increased with the level of concentrate. Milk conversion efficiency per $\mathrm{kg}$ of DM intake was similar between treatments while expressed as an energy consumed basis resulted lower in T10.5 without differences between T3.5 and T7.0.

\subsection{Changes in Body Weight and Body Condition Score}

No treatment effect was detected for any of the variables associated with the variation of body reserves although the loss of BW in group T3.5 was $80 \%$ higher than observed in T10.5 (Table 4).

\subsection{Plasma Concentration of Metabolites and Hormones}

Despite the increased $\mathrm{NE}_{\mathrm{L}}$ intake (Table 3), circulating levels of glucose, insulin and IGF-I were not affected by the treatments (Table 5).

The absence of treatment effect on changes in BW and BCS is compatible with the similar plasma NEFA and insulin concentation. Uremia was significantly lower in T10.5, a result consistent with the lower values of milk urea content registered in that treatment.

Table 4. Changes in body weight and body condition score in grazing dairy cows supplemented with 3.5 (T3.5), 7.0 (T7.0) and 10.5 (T10.5) $\mathrm{kg} \mathrm{cow}^{-1} \mathrm{~d}^{-1}$ of concentrate.

\begin{tabular}{cccccc}
\hline Variable & \multicolumn{3}{c}{ Treatment $^{1}$} & \multirow{2}{*}{ SEM } & \multirow{2}{*}{$\boldsymbol{p}^{2}$} \\
\cline { 2 - 4 } & T3.5 & T7.0 & T10.5 & & 0.86 \\
Initial BW, kg & 603.5 & 601.2 & 604.8 & 14.6 & 0.19 \\
Final BW, kg & 588.0 & 591.2 & 596.2 & 13.9 & 0.63 \\
BW change, kg & -15.5 & -10.0 & -8.6 & 5.3 & 0.64 \\
Initial BCS, 1 a 5 & 2.48 & 2.50 & 2.46 & 0.07 & 0.79 \\
Final BCS, 1 a 5 & 2.46 & 2.43 & 2.44 & 0.07 & 0.68 \\
Change & -0.01 & -0.07 & -0.03 & 0.05 & \\
\hline
\end{tabular}

${ }^{1}$ Values are expressed as least square means (LSMeans) and standard error of LSMeans (SEM). ${ }^{2}$ Effects of treatment (Treat); ${ }^{\mathrm{a}, \mathrm{b}}$ Within rows LSMeans with different superscripts differ (Tukey-Kramer test, $p<0.05$ ).

Table 5. Plasma metabolite and hormone concentrations in grazing dairy cows supplemented with 3.5 (T3.5), 7.0 (T7.0) and 10.5 (T10.5) kg/cow d ${ }^{-1}$ of energy concentrate.

\begin{tabular}{|c|c|c|c|c|c|c|}
\hline \multirow{2}{*}{ Parameter } & \multicolumn{3}{|c|}{ Treatment $^{1}$} & \multirow{2}{*}{ EEM } & \multicolumn{2}{|c|}{$P<^{2}$} \\
\hline & T3.5 & T7.0 & T10.5 & & Treat & Period \\
\hline Glucose, $\mathrm{mmol} \cdot \mathrm{l}^{-1}$ & 1.99 & 2.14 & 2.21 & 0.13 & 0.23 & 0.01 \\
\hline Urea, mmol.1 $\mathrm{l}^{-1}$ & $8.10^{\mathrm{a}}$ & $8.38^{\mathrm{a}}$ & $7.38^{\mathrm{b}}$ & 0.29 & 0.04 & 0.01 \\
\hline $\mathrm{AGNE}, \mu \mathrm{Eq} \cdot 1^{-1}$ & 361.56 & 296.22 & 333.89 & 24.13 & 0.19 & 0.57 \\
\hline $\mathrm{GH}, \mathrm{ng} \cdot \mathrm{ml}^{-1}$ & 5.74 & 6.38 & 6.11 & 2.26 & 0.98 & 0.28 \\
\hline Insulin, $\mathrm{ng} \cdot \mathrm{ml}^{-1}$ & 0.70 & 0.59 & 0.88 & 0.17 & 0.26 & 0.10 \\
\hline IGF-I, ng.ml ${ }^{-1}$ & 139.03 & 125.00 & 130.24 & 10.11 & 0.62 & 0.10 \\
\hline
\end{tabular}

${ }^{1}$ Values are expressed as least square means (LSMeans) and standard error of LSMeans (SEM). ${ }^{2}$ Effects of treatment (Treat) and period. ${ }^{a, b}$ Within rows LSMeans with different superscripts differ (Tukey-Kramer test, $p<0.05)$. NEFA = non esterified fatty acids; $\mathrm{GH}=$ somatotrophin; IGF-I = somatomedin C. 


\subsection{Ruminal Environment and Pasture NDF Digestion}

The treatment $\times$ hour interaction was not significant for any variable of ruminal environment. Total VFA concentration was significantly higher in T3.5 without differences between T.7 and T10.5. This result could be linked to the observed increase in the acetate and butyrate concentrations (Table 6). The molar proportions of VFA were not affected by treatments. The $\mathrm{pH}$ values decreased with the increase in concentrate intake. The concentration of $\mathrm{NH}_{3}-\mathrm{N}$ in T10.5 resulted significantly lower respect to T3.5 but similar to that observed in T7.0 without differences between T3.5 and T7.0. This result was consistent with the lowest values of plasma and milk urea concentrations observed in T10.5.

Increasing levels of concentrate intake tended $(p<0.12)$ to decrease the fractional rate of forage $\mathrm{CW}$ degradation. The effective degradability of forage $\mathrm{CW}$ decreased between 8.3 to 9.7 percentage points with the increase in concentrate intake, a result consistent with the decrease in ruminal $\mathrm{pH}$ values observed as concentrate intake increased. The rest of the parameters associated with the kinetics of ruminal CW digestion were not affected (Table 7).

Table 6. Parameters of rumen environment in grazing dairy cows supplemented with 3.5 (T3.5), $7.0(7.0)$ and $10.5(\mathrm{~T} 10.5) \mathrm{kg} / \mathrm{cow} \mathrm{d} \mathrm{d}^{-1}$ of an energy concentrate.

\begin{tabular}{|c|c|c|c|c|c|c|c|}
\hline \multirow{2}{*}{ Parameter } & \multicolumn{3}{|c|}{ Treatment $^{1}$} & \multirow{2}{*}{ SEM } & \multicolumn{3}{|c|}{$p<<^{2}$} \\
\hline & T3.5 & T7.0 & $\mathrm{T} 10.5$ & & Treat & Hour & Treat * Hour \\
\hline Total VFA, mmol. $\mathrm{L}^{-1}$ & $176.1^{\mathrm{a}}$ & $129.4^{\mathrm{b}}$ & $133.9^{b}$ & 6.62 & 0.01 & 0.01 & 0.22 \\
\hline Ac, $\mathrm{mmol} \cdot \mathrm{L}^{-1}$ & $105.9^{\mathrm{a}}$ & $77.0^{\mathrm{b}}$ & $83.7^{\mathrm{b}}$ & 4.12 & 0.01 & 0.01 & 0.29 \\
\hline Ac, mol $100 \mathrm{~mol}^{-1}$ & 60.0 & 59.3 & 62.6 & 0.89 & 0.07 & 0.74 & 0.93 \\
\hline $\mathrm{Pr}, \mathrm{mmol} \cdot \mathrm{L}^{-1}$ & 41.6 & 31.9 & 29.1 & 4.54 & 0.24 & 0.01 & 0.16 \\
\hline $\operatorname{Pr}, \mathrm{mol} 100 \mathrm{~mol}^{-1}$ & 23.7 & 24.7 & 21.6 & 0.92 & 0.11 & 0.78 & 0.98 \\
\hline Butyrate, $\left(\mathrm{mmol} \cdot \mathrm{L}^{-1}\right)$ & $22.0^{\mathrm{a}}$ & $14.1^{\mathrm{b}}$ & $15.5^{\mathrm{b}}$ & 0.76 & 0.01 & 0.01 & 0.16 \\
\hline Butyrate, mol $100 \mathrm{~mol}^{-1}$ & 11.9 & 10.9 & 11.5 & 0.12 & 0.11 & 0.01 & 0.13 \\
\hline Ac:Pr ratio & 2.59 & 2.55 & 2.95 & 0.35 & 0.70 & 0.08 & 0.21 \\
\hline $\mathrm{pH}$ & $6.07^{\mathrm{a}}$ & $6.03^{\mathrm{ab}}$ & $5.81^{\mathrm{b}}$ & 0.07 & 0.02 & 0.04 & 0.66 \\
\hline $\mathrm{NH}_{3}-\mathrm{N}, \mathrm{mg} \cdot \mathrm{dl}^{-1}$ & $49.11^{\mathrm{a}}$ & $44.63^{\mathrm{ab}}$ & $36.17^{\mathrm{b}}$ & 5.49 & 0.01 & 0.09 & 0.94 \\
\hline
\end{tabular}

${ }^{1}$ Values are expressed as least square means (LSMeans) and standard error of LSMeans (SEM). ${ }^{2}$ Effects of treatment (Treat), Hour and Treat ${ }^{*}$ Hour interaction. ${ }^{\mathrm{a}, \mathrm{b}, \mathrm{c}}$ Within rows LSMeans with different superscripts differ (Tukey-Kramer test, $p<0.05)$. VFA = volatile fatty acids.

Table 7. Parameters of pasture NDF degradation in grazing dairy cows supplemented with 3.5 (T3.5), 7.0 (7.0) and 10.5 (T10.5) kg/cow d ${ }^{-1}$ of ane energy concentrate.

\begin{tabular}{|c|c|c|c|c|c|}
\hline \multirow{2}{*}{ Variable } & \multicolumn{3}{|c|}{ Tratamiento $^{1}$} & \multirow{2}{*}{ EEM } & \multirow{2}{*}{$p<^{2}$} \\
\hline & T3.5 & T7.0 & T10.5 & & \\
\hline \multicolumn{6}{|l|}{ Cell Wall (CW) } \\
\hline PDFCW, \% & 54.08 & 54.55 & 50.00 & 4.06 & 0.69 \\
\hline FRDCW, \% hour ${ }^{-1}$ & 12.17 & 8.29 & 7.53 & 0.95 & 0.12 \\
\hline Lag time, hours & 0.13 & 1.78 & 1.05 & 0.92 & 0.55 \\
\hline \multicolumn{6}{|l|}{ Effective degradability, ${ }^{3}$} \\
\hline $\mathrm{kp}=5 \%$ hour $^{-1}$ & $38.09^{\mathrm{a}}$ & $29.82^{\mathrm{b}}$ & $28.38^{\mathrm{c}}$ & 0.32 & 0.01 \\
\hline
\end{tabular}

${ }^{1}$ Values are expressed as least square means (LSMeans) and standard error of LSMeans (SEM). ${ }^{2}$ Treatment (Treat) and period effects. ${ }^{3}$ Rate of passage [22]. a,b,c Within rows LSMeans with different superscripts differ (Tukey-Kramer test, $p<0.05)$. PDFCW = Potentially digestible fraction of cell wall; FRDCW = fractional rate of cell wall digestión. 


\section{Discussion}

\subsection{Pasture Quality}

Herbage allowance ( $\mathrm{kg} \mathrm{DM} / \mathrm{cow}$ day $\left.^{-1}\right)$ and pasture biomass (kg DM/Ha) are two non-nutritional factors that affect voluntary intake of grazing animals [33]. To maximize pasture intake, an herbage allowance of at least $31 \mathrm{~kg} \mathrm{DM} / \mathrm{cow}$ day $^{-1}$ is needed [34] [35] and with alfalfa pastures under rotational grazing, maximum pasture DM intake $\left(19.5 \mathrm{~kg} \mathrm{DM} /\right.$ cow day $\left.{ }^{-1}\right)$ was observed at an herbage allowance of $30 \mathrm{~kg} \mathrm{DM} /$ cow day ${ }^{-1}$ [36]. When high quality forage biomass is around $2000 \mathrm{~kg} \mathrm{DM} \mathrm{ha}^{-1}$ and then close to the average value recorded in the present trial, maximum herbage intake would be achieved when the grazing time is not restricted [37]. Pasture CP content (Table 1) was within the range (150 $250 \mathrm{~g} \mathrm{CP} \mathrm{kg} \mathrm{DM}^{-1}$ ) proposed by [37] in order to obtain a high DM digestibility. In our trial, pasture DM content (Table 1) was above the critical range of $15 \%$ $18 \%$ that would negatively affect herbage intake [38]. Pasture NDF content (Table 1) was well below the values considered critical (500 - $550 \mathrm{~g}$ NDF kg $\mathrm{DM}^{-1}$ ) for high forage intake and adequate production of milk [39]. It could be concluded that forage quantity and quality did not limit pasture DM intake.

\subsection{Milk Yield and Composition}

Milk production increased with level of concentrate but above $7 \mathrm{~kg} / \mathrm{cow}$ day $^{-1}$ additional changes were not detected (Table 2). In controlled feeding conditions when pasture silage was the only forage source and total energy intake was kept constant, the maximum response in milk production was observed when glucogenic energy intake was about 8-10 $\mathrm{Mcal} \mathrm{EN}_{\mathrm{L}}$ in cows producing $27-30 \mathrm{~kg}$ milk $\mathrm{day}^{-1}$ [24]. These results are consistent with those obtained in the present work and contribute to explain the lack of milk response when cows consumed T7.0 and $10.5 \mathrm{~kg}$ of concentrate since glucogenic energy intake (8.98 and 9.67 Mcal Table 3) was in the limit zone (plateau) of the response in milk production.

Feeding energy concentrates to grazing dairy cows increased milk protein content [6] [40] a result not observed in this study (Table 2). The increase would be explained by a higher proportion of ruminal propionate and enhanced rumen microbial protein synthesis [40] [41] with a concomitant increase in the amino acid available at the small intestine. The absorbed amino acids together with preformed or neo synthesized glucose from propionate in the liver represent the main substrate for milk protein synthesis. Increases in milk protein concentration $(+0.04 \%)$ for each extra Mcal of GE consumed in a range from 4 to 12 $\mathrm{Mcal} /$ day were reported in [24]. According to the estimated GE intake achieved in the present trial (Table 3) an increase in milk protein content would have been expected. The lack of a significant increase in milk protein content was probably masked by a dilution effect when milk production was enhanced. Milk protein yield increased linearly with concentrate intake (Table 2) a result also reported when dairy cows grazed alfalfa-ryegrass based pastures and were supplemented at 0,5 and $10 \mathrm{~kg} \mathrm{DM} /$ day with a corn-based concentrate [42]. 
Milk fat content was not affected by concentrate intake (Table 2) a result not observed by [6] who reported a linear decrease in milk fat when levels of concentrate increased up to $10 \mathrm{~kg} \mathrm{DM} /$ day in grazing dairy cows. The main factor affecting milk fat percentage is the fiber content of the diet [43]. To prevent reductions in milk fat content, dairy cow diets should contain a minimum of $25 \%$ NDF with $16 \%$ of the NDF provided by forage [23]. In the present trial, even in cows that consumed the highest dose of concentrate, the NDF content in total diet represented $31.5 \%$ with $24.6 \%$ NDF arising from forage. This amount of fiber was apparently sufficient enough to avoid a decrease in milk fat content or fat yield (Table 2). A significant reduction in milk fat concentration and yield in grazing cows was reported when energy concentrate exceeded 50\% DM of the diet [44]. In the present work, concentrate intake represented only $40.7 \%$ of total DM in T10.5 which would contribute to explain the absence of effects on milk fat.

When pasture silage was the only forage source, an increase in the availability of glucose and glucogenic precursors maximized lactose synthesis [24] [45] [46]. In our study, lactose content increased linearly with the level of concentrate intake (Table 2).

Yields of 4\% FCM and ECM increased with concentrate intake without additional differences between T7.0 and T10.5 (Table 2). In grazing dairy cows, a curvilinear relationship was reported for yield of 4\% FCM when intake of a cereal based concentrate increased from 0 to $10.4 \mathrm{~kg} \mathrm{DM} / \mathrm{cow} \mathrm{day}^{-1}$ but it tended to plateau before reaching the highest levels of concentrate intake [44].

This pattern of response would be explained by two mechanisms, an increase in substitution rate of pasture by concentrate and a decrease in ruminal $\mathrm{pH}$ affecting forage fiber digestion as the level of concentrate increases [47]. In the present work pasture substitution rate did not increase with the level of supplementation averaging 0.56 or 0.23 between T7.0 and T10.5. However, increasing levels of concentrate caused a decrease in ruminal $\mathrm{pH}$ and affected the effective degradability of forage FDN (Table 7). This result may explain in part the absence of changes in yield of 4\% FCM and ECM when the level of supplementation exceeded $30 \%$ of total DM intake.

Milk urea and ruminal $\mathrm{NH}_{3}-\mathrm{N}$ concentrations decreased as concentrate intake was enhanced (Table 2 and Table 6) according to results from [9] [43] suggesting an improved nitrogen utilization in supplemented cows.

\subsection{DM and Energy Intake}

Pasture intake decreased $\left(-3.6 \mathrm{~kg} \cdot \mathrm{day}^{-1}\right)$ and total DM intake increased $(+2.8$ $\mathrm{kg} \cdot \mathrm{day}^{-1}$ ) when cows consumed 10.5 compared to $3.5 \mathrm{~kg} /$ cow day ${ }^{-1}$ concentrate (Table 3) results that resulted consistent with those reviewed by [6] in grazing dairy cows. The inclusion of supplements generally depresses pasture DM intake in grazing dairy cows although the relationship between the amount of supplement fed and the substitution rate is somehow inconsistent [6]. Substitution rate 
may be linked to a lower ruminal $\mathrm{pH}$ that may affect the rate of forage NDF digestion and hence pasture intake [48]. In our study, supplementation with increasing levels of concentrate reduced the effective degradability of forage FDN (Table 7), which would help explain the higher substitution rate observed between T7.0 and T10.5.

As pasture $\mathrm{NE}_{\mathrm{L}}$ intake decreased after supplementation $(-4.05$ and -5.12 $\mathrm{Mcal} /$ cow d ${ }^{-1}$ for T7.0 and T10.5, respectively) the increase in total $\mathrm{NE}_{\mathrm{L}}$ intake (Table 3) was explained by energy arising from the concentrate (6.51 and 13.02 Mcal $\mathrm{d}^{-1}$ for T7.0 and T10.5, respectively). The conversion efficiency of consumed DM was similar between treatments while that of $\mathrm{NE}_{\mathrm{L}}$ resulted lower in T10.5 compared to T3.5 and T7.0 (Table 3). Since in T3.5 the cows apparently mobilized greater endogenous energy to sustain milk production (Table 4) the real differences in conversion efficiency could partly be masked. The lack of response in efficiency was mainly explained by the high substitution rates observed, although the differences between treatments in the mobilization of body reserves could have also contributed to explain this result.

\subsection{Changes in BW, BCS and Plasma Metabolite and Hormone Concentration}

The lack of changes in parameters associated to body energy stores after concentrate feeding (Table 4) were aldo reported in other studies [9] [49]. It is important to state that changes in $\mathrm{BW}$ is an imprecise parameter because real records may be masked in part by filling effects explained by DM intake, digestive tract content and other factors like changes in uterine involution. Circulating plasma NEFA are more useful indicators to reflect changes in lipomobilization in short-term periods but this parameter was also not affected by treatments (Table 5) keeping with the absence of differences in body parameters. Plasma glucose and regulatory hormones such as insulin, GH and IGF-I also act as dynamic or short-term indicators of energy balance [50] [51]. When cows are in negative energy balance, a decrease in plasma glucose, insulin and IGF-I concentrations are expected with a concomitant increase in NEFA [52] [53]. In this trial, plasma glucose and insulin concentrations were similar between treatments (Table 5). Liver production of IGF-I is positively correlated with energy intake and circulating GH levels [54] but even though the higher energy intake plasma concentration of IGF-I was not affected (Table 5) a result compatible with the similar circulating levels of $\mathrm{GH}$.

Milk urea is derived mainly from blood urea which in turn arise from ruminal $\mathrm{N}-\mathrm{NH}_{3}$ excess and amino acids catabolism in the liver [55]. The lower plasma concentration of urea in T10.5 (Table 5) kept with the observed lower ruminal concentration of $\mathrm{N}-\mathrm{NH}_{3}$ (Table 6) and urea in milk (Table 2).

\subsection{Ruminal Environment and Digestion}

The lower ruminal $\mathrm{pH}$ associated with the increase in concentrate intake (Table 
6) was an effect also reported in the review of [6] when energy concentrate intake ranged from 1.1 to $10 \mathrm{~kg} \mathrm{DM} / \mathrm{cow} \mathrm{day}^{-1}$. Intake of fermentable non-structural carbohydrates decrease chewing and rumination, reduce ruminal motility, change VFA production and reduce the buffer capacity leading to a decreased ruminal pH. In line with previous studies [9] [10] [42] the lower ruminal $\mathrm{N}-\mathrm{NH}_{3}$ concentration (Table 6) was probably reflecting a higher capture of $\mathrm{N}-\mathrm{NH}_{3}$ because total CP intake was similar between treatments $\left(4.80 \pm 0.13 \mathrm{~kg} \cdot \mathrm{day}^{-1}, p=\right.$ 0.11 ). As unexpected, the highest total VFA concentration was observed with the lower concentrate intake in the $\mathrm{T} 3.5$ (Table 6) a result probably explained by the high quality of the pastures (Table 1) that lead to a high VFA production [56].

Concentration of VFA in ruminal fluid depends on the balance between production and absorption through ruminal wall and the rate of absorption is directly related to VFA production and inversely with ruminal $\mathrm{pH}$ thus preventing its accumulation in the rumen [57]. It was also reported that the fractional absorption rates of propionic and butyric VFA increased as the $\mathrm{pH}$ decreased from 7.2 to 4.5 [57]. In the $\mathrm{pH}$ range observed in the present experiment (5.57 - 6.33) it is possible that the absorption rates of propionic and butyric acids were high, while the acetic acid absorption rate was not affected by the $\mathrm{pH}$ level partly explaining the higher total VFA concentration recorded in T3.5. The lack of effect on ruminal VFA proportions or in the acetate: propionate ratio (Table 6) was consistent with the similar milk fat content (Table 2).

The observed trend to lower forage cell wall degradation $(p<0.12)$ and the lower degradability of forage FDN (Table 6) were previously observed in [9]

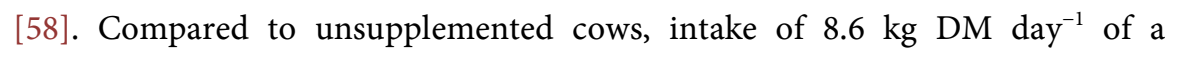
corn-based concentrate reduced pasture DM and NDF degradation [9]. Increasing levels of a barley based concentrate from 4.5 to $8.1 \mathrm{~kg} \mathrm{DM} /$ cow day ${ }^{-1}$ affected pasture NDF digestibility [58]. It is generally accepted that NDF digestion is affected when the ruminal $\mathrm{pH}$ falls below 6.0 [59]. The average ruminal $\mathrm{pH}$ registered in T10.5 (5.81, Table 6), would contribute to explain the reduction in the effective NDF degradability of the pasture observed in that treatment. In alfalfa based pastures, feeding increased levels of energy concentrate caused a decrease in ruminal $\mathrm{pH}$ negatively affecting digestion pasture FDN without effects on milk fat content.

\subsection{Integration of Experimental Results on Concentrate Feeding Levels}

Results obtained from similar trials carried out at INTA [22] [60] [61] were analyzed by multiple regression with the incorporation of qualitative variables [62] to remove effects associated to different groups of animals, years and statistical designs. The parallelism and coincidence test were also implemented. Concentrate composition was similar for the four trials involved. Intake of concentrate ranged between 2.7 and $11.6 \mathrm{~kg} \mathrm{DM} / \mathrm{cow}^{-1} \mathrm{day}^{-1}$ and herbage allowance from 27.0 to $35.9 \mathrm{~kg} \mathrm{DM} \mathrm{cow}^{-1}$ day $^{-1}$. Parameters of pasture quality ranged from $20.3 \%$ to 
$30.8 \%$ for DM, $18.3 \%$ to $25.1 \%$ for CP; $34.8 \%$ to $50.2 \%$ for NDF; $19.9 \%$ to $25.8 \%$ $\mathrm{ADF}$ and $69.6 \%$ to $75.2 \%$ in vitro DM digestibility. Average milk production at the start of the trials was $34.1 \mathrm{~kg} / \mathrm{cow} \mathrm{day}^{-1}$. The four regression lines for milk production were parallel and coincident and the following marginal response equation was obtained: Milk $\left(\mathrm{kg} / \mathrm{cow} \mathrm{day}^{-1}\right)=25.95+0.774 * \mathrm{~kg}$ concentrate $\mathrm{DM}\left(p<0.042, \mathrm{R}^{2}=0.37\right)$. The equation suggest that unsupplemented cows may produce up to $25.95 \mathrm{~kg}$ milk when only pasture is fed and above this yield milk production increases linearly at a rate of $0.774 \mathrm{~kg}$ milk per $\mathrm{kg}$ DM of additional concentrate as the amount of concentrate intake increases from 2.7 to $11.6 \mathrm{~kg}$ $\mathrm{MS} /$ cow day ${ }^{-1}$. For the rest of the variables of production and composition of milk analyzed, the lines were parallel but not coincident giving rise to 4 different equations. The immediate or marginal response is one that is expressed in the short term after supplementation resulting from total nutrients absorbed and the way they are partitioned between milk production and weight gain. It has been described as curvilinear with increasing amounts of concentrate [42]. Thus, in some studies the marginal response decreased above intakes of 3 to $4 \mathrm{~kg} \mathrm{DM}$ $\mathrm{day}^{-1}$ of concentrate for cows of moderate (less than $25 \mathrm{~kg} \cdot \mathrm{day}^{-1}$ ) milk production potential [62]. The greater response to concentrate supplementation in cows of high genetic merit can be attributed to a greater partition of nutrients for milk production with respect to cows with lower production potential [63]. The linear increase in milk production observed in the present work was similar to that reported by [6] in high yielding dairy cows producing from 28.3 to $45.8 \mathrm{~kg}$ milk day $^{-1}$ supplemented with increasing levels of concentrate in a range of 1.8 to 10 $\mathrm{kg} \mathrm{DM} \mathrm{day}^{-1}$. The average production level of the cows used in the trials included in the present analysis was within the range reported in [6]. However, the marginal response obtained in the present work (0.774) was lower than reported in [6]. Substitution rate is higher when herbage mass is not limiting pasture intake and in one of the main factors affecting the productive response to supplementation [64]. Responses (kg milk/kg concentrate) of 0.4 to 0.6 and 0.92 were reported in [64] for papers published before and after 1990 respectively and the increase in the marginal was explained by the decrease in susbstitution rate from 0.6 to $0.4 \mathrm{~kg}$ DM pasture/ $\mathrm{kg}$ DM concentrate. The substitution rate observed in two trials of the present analysis was near to 0.6 and then contributed to explain the global lower marginal response obtained with respect to trials reviewed in [65].

\section{Conclusion}

Increasing intake levels of energy concentrate improved yields of milk, 4\% FCM and ECM without additional responses when concentrate represented more than $30 \%$ of total dry matter intake of grazing cows producing about $30 \mathrm{~kg}$ milk day $^{-1}$ without affecting chemical composition of the milk. The increase in total DM and energy intake explained in part the lack of positive effects on conversion efficiency although the increased energy absorbed was not apparently channeled 
to body reserves or lower lipid mobilization results that were consistent with the lack of effect on changes in insulin and growth hormone concentrations that may induce alterations in the partition of the absorbed energy. Results obtained suggest that in order to avoid negative effects on pasture fiber digestion starch based concentrate intake does not exceed $30 \%$ of total dry matter intake of cows.

\section{Acknowledgements}

This work was supported by the National Institute of Agricultural Technology (INTA). This Institute is a decentralized state agency with operational and financial autarchy under the Ministry of Agroindustry of the Argentine Republic. This publication is part of the requirements for access to the academic degree of Doctor in Agricultural Sciences by the Mar del Plata National University, Argentina by Mr. E. Salado.

\section{Conflicts of Interest}

The authors declare no conflicts of interest regarding the publication of this paper.

\section{References}

[1] Dillon, P., Hennessy, T., Shalloo, L., Thorne, F. and Horan, B. (2008) Future Outlook for the Irish Dairy Industry: A Study of International Competitiveness, Influence of International Trade Reform and Requirement for Change: Review. International Journal Dairy Technology, 61, 16-29. https://doi.org/10.1111/j.1471-0307.2008.00374.x

[2] Kolver, E.S. (2003) Nutritional Limitations to Increased Production on PastureBased Systems. Proceedings Nutritional Society, 62, 291-300. https://doi.org/10.1079/PNS2002200

[3] Kolver, E.S. and Muller, L.D. (1998) Performance and Nutrient Intake of High Producing Holstein Cows Consuming Pasture or a Total Mixed Ration. Journal of Dairy Science, 81, 1403-1411. https://doi.org/10.3168/jds.S0022-0302(98)75704-2

[4] Delaby, L. and Peyraud, J.L. (1997) Influence of Concentrate Supplementation Strategy on Grazing Dairy Cow's Performance. In: Christie, B.R., Ed., Proceedings of the XVIII International Grassland Congress, Winnipeg, 137-138.

[5] Gagliostro, G.A. and Chilliard, Y. (1992) Review. Protected Lipid Utilization in Dairy Cows Nutrition. II. Effects on Plasma Metabolites and Hormones, Body Lipid Mobilization and Metabolic Activity of Adipose Tissue. Revista Argentina de Producción Animal, 12, 17-32.

[6] Bargo, F., Muller, L.D., Kolver, E.S. and Delahoy, J.E. (2003) Invited Review: Production and Digestion of Supplemented Dairy Cows on Pasture. Journal of Dairy Science, 86, 1-42. https://doi.org/10.3168/jds.S0022-0302(03)73581-4

[7] Delaby, L. and Peyraud, J.L. (2003) The Effect of Two Contrasting Grazing Managements and Level of Concentrate Supplementation on the Performance of Grazing Dairy Cows. Animal Research, 52, 437-460.

https://doi.org/10.1051/animres:2003030

[8] Beever, D.E. and Siddons, R.C. (1986) Digestion and Metabolism in Grazing Rumi- 
nants. In: Milligan, L.P., Grovum, W.L. and Dobson, A., Eds., Control of Digestion and Metabolism in Ruminants, Prentice-Hall, Banff, 479-497.

[9] Bargo, F., Muller, L.D., Delahoy, J.E. and Cassidy, T.W. (2002) Milk Response to Concentrate Supplementation of High Producing Dairy Cows Grazing at Two Pasture Allowances. Journal of Dairy Science, 85, 1777-1792. https://doi.org/10.3168/jds.S0022-0302(02)74252-5

[10] Leddin, C.M., Stockdale, C.R., Hill, J., Heard, J.W. and Doyle, P.T. (2010) Increasing Amounts of Crushed Wheat Fed with Persian Clover Herbage Reduced Ruminal pH and Dietary Fibre Digestibility in Lactating Dairy Cows. Animal Production Science, 50, 837-846. https://doi.org/10.1071/AN09157

[11] Meijs, J.A.C., Walters, R.J.K. and Keen, A. (1982) Sward Methods. In: Herbage Intake Handbook, British Grassland Society Ed., 11-36.

[12] Komarek, A.R. (1993) An Improved Filtering Technique for the Analysis of Neutral Detergent Fiber and Acid Detergent Fiber Utilizing the Filter Bag Technique. Ankom Tech. Corp., Fairport, Publication No. 101, 1-10.

[13] AOAC (Association of Official Analytical Chemists) (1990) Official Methods of Analysis. 15th Edition, AOAC, Washington DC.

[14] AOAC (Association of Official Analytical Chemists) (1998) Official Methods of Analysis. 16th Edition, AOAC, Arlington.

[15] Tilley, J.M.A. and Terry, R.A. (1963) A Two-Stage Technique for in Vitro Digestion of Forage Crops. Journal British Grassland Society, 18, 104-111. https://doi.org/10.1111/j.1365-2494.1963.tb00335.x

[16] Mcrae, J.E. and Armstrong, D.G. (1968) Enzyme Method for Determination of Alpha-Linked Glucose Polymers in Biological Materials. Journal Science Food Agriculture, 19, 578-581. https://doi.org/10.1002/jsfa.2740191006

[17] Ovejero, F. (1987) Chemical and Biological Chemical Evaluation of Forages. Dirección de Desarrollo de Recursos Humanos.

[18] Gaines, W.L. and Davidson, F.A. (1923) Relation between Percentage of Fat Content and Yield of Milk. University of Illinois, Chicago, 245.

[19] Tyrrell, H.F. and Reid, J.T. (1965) Prediction of the Energy Value of Cow's Milk. Journal of Dairy Science, 48, 1215-1223. https://doi.org/10.3168/jds.S0022-0302(65)88430-2

[20] Wildman, E.E., Jones, G.M., Wagner, P.E., Boman, R.L., Troutt, H.F. and Lesch, T.N. (1982) A Dairy Cow Body Condition Scoring System and Its Relationship to Selected Production Characteristics. Journal of Dairy Science, 65, 495-501. https://doi.org/10.3168/jds.S0022-0302(82)82223-6

[21] Salado, E.E., Gagliostro, G.A., Becu-Villalobos, D. and Lacau-Mengido, I. (2004) Partial Replacement of Corn Grain by Hydrogenated Oil in Grazing Dairy Cows in Early Lactation. Journal of Dairy Science, 87, 1265-1278. https://doi.org/10.3168/jds.S0022-0302(04)73277-4

[22] Salado, E.E., Bretschneider, G., Cuatrin, A., Descalzo, A.M. and Gagliostro, G.A. (2017) Milk Yield and Composition and Pasture Ruminal Digestion in Grazing Dairy Cows Receiving Three Levels of Energy Concentrate Supplementation. Agricultural Sciences, 8, 1135-1156. https://doi.org/10.4236/as.2017.810083

[23] National Research Council (2001) Nutrient Requirements of Dairy Cattle. 7th Revision Edition, National Academy Press, Washington DC.

[24] Rigout, S., Hurtaud, C., Lemosquet, S., Bach, A. and Rulquin, H. (2003) Lactational 
Effect of Propionic Acid and Duodenal Glucose in Dairy Cows. Journal of Dairy Science, 86, 243-253. https://doi.org/10.3168/jds.S0022-0302(03)73603-0

[25] Huntington, G.B. (1997) Starch Utilization by Ruminants: From Basics to the Bunk. Journal of Animal Science, 75, 852-867. https://doi.org/10.2527/1997.753852x

[26] Mehrez, A.Z. and Ørskov, E.R. (1977) A Study of the Artificial Fibre Bag Technique for Determining the Digestibility of Feeds in the Rumen. Journal of Agricultural Science Cambridge, 88, 645-650. https://doi.org/10.1017/S0021859600037321

[27] Mertens, D.R. and Loften, J.R. (1980) The Effect of Starch on Forage Fiber Digestion Kinetics in Vitro. Journal of Dairy Science, 63, 1437-1446. https://doi.org/10.3168/jds.S0022-0302(80)83101-8

[28] Fernández, H.H. (2004) A Simple Procedure for Estimate Useful Functions in Animal Production Using Solver from Excel. Revista Argentina de Producción Animal, 24, 75-85.

[29] Gaggiotti, M.G., Salado, E.E., Gallardo, M.R., Arakaki, L.C., Valtorta, S.E. and Castro, H.C. (2007) In Situ Degradation of Rapeseed and Soybean Meal and the Effects of Its Supplementation on the Ruminal Environment of Dairy Cows with Access to Alfalfa Grazing. 20th Reunión Latinoamericana de Producción Animal, Cusco, 22-25 Octubre 2007.

[30] Friggens, N.C., Oldham, J.D., Dewhurst, R.J. and Horgan, G. (1998) Proportions of Volatile Fatty Acids in Relation to the Chemical Composition of Feeds Based on Grass Silage. Journal of Dairy Science, 81, 1331-1344. https://doi.org/10.3168/jds.S0022-0302(98)75696-6

[31] SAS Institute Inc. (1999) SAS/STAT User's Guide (Release 8.0). SAS Institute, Cary.

[32] Gaggiotti, M. (2008) Table of Chemical Composition of Foods for Ruminants. INTA Editions, $67 \mathrm{p}$.

[33] Poppi, D.P., Hughes, T.P. and L'Huillier, P.J. (1987) Intake of Pasture by Grazing Ruminants. In: Nicol, A.M., Ed., Livestock Feeding on Pasture, Occ. Pub. No. 10, Hamilton, New Zealand Society of Animal Production, 55-64.

[34] Baudracco, J., Lopez-Villalobos, N., Romero, L.A., Scandolo, D., Maciel, M., Comeron, E.A., Holmes, C.W. and Barry, T.N. (2011) Effects of Stocking Rate on Pasture Production, Milk Production and Reproduction of Supplemented Crossbred Holstein-Jersey Dairy Cows Grazing Lucerne Pasture. Animal Feed Science and Technology, 168, 131-143. https://doi.org/10.1016/j.anifeedsci.2011.03.017

[35] Leaver, J.D. (1985) Milk Production from Grazed Temperate Grassland. A Review. Journal of Dairy Research, 52, 313-344. https://doi.org/10.1017/S0022029900024201

[36] Romero, L.A., Comeron, E.A., Bruno, O.A. and Diaz, M.C. (1995) Effect of Herbage Allowance on Performances of Dairy Cows Grazing Alfalfa Swards. 1. Intake and Ingestive Behaviour. Revista Argentina de Producción Animal, 15, 623-626.

[37] Minson, D.J. (1990) Forage in Ruminant Nutrition. Academic Press, Inc., Queensland.

[38] Verité, R. and Journet, M. (1970) Effect of the Water Content of Grass and Dehydration at Low Temperature upon Its Feeding Value for Dairy Cows. Annales de Zootechnie, 19, 255-268.

[39] Paterson, J.A., Belyea, R.L., Bowman, J.P., Kerley, M.S. and Williams, J.E. (1994) The Impact of Forage Quality and Supplementation Regimen on Ruminant Animal Intake and Performance. In: Fahey Jr., G.C., Ed., Forage Quality, Evaluation and Utilization, American Society of Agronomy, Inc. Crop Science Society of America, 
Soil Science Society of America, Inc., Madison, 59-114.

[40] Kellaway, R. and Harrington, T. (2004) Feeding Concentrates Supplements for Dairy Cows. Revised Edition, Landlinks Press, Collingwood, $171 \mathrm{p}$.

[41] Beever, D.E. and Doyle, P.T. (2007) Feed Conversion Efficiency as a Key Determinant of Dairy Herd Performance: A Review. Australian Journal Experimental Agriculture, 47, 645-657. https://doi.org/10.1071/EA06048

[42] Reis, R.B. and Combs, D.K. (2000) Effects of Increasing Levels of Grain Supplementation on Rumen Environment and Lactation Performance of Dairy Cows Grazing Grass-Legume Pasture. Journal of Dairy Science, 83, 2888-2898. https://doi.org/10.3168/jds.S0022-0302(00)75189-7

[43] Kellaway, R. and Porta, S. (1993) Feeding Concentrates Supplements for Dairy Cows. Dairy Research and Development Corporation, Melbourne.

[44] Walker, G.P., Stockdale, C.R., Wales, W.J., Doyle, P.T. and Dellow, D.W. (2001) Effect of Level of Grain Supplementation on Milk Production Responses of Dairy Cows in Mid-Late Lactation When Grazing Irrigated Pastures High in Paspalum (Paspalum dilatatum Poir). Australian Journal of Experimental Agriculture, 41, 1-11. https://doi.org/10.1071/EA00076

[45] Rigout, S., Lemosquet, S., van Eys, J.E., Blum, J.W. and Rulquin, H. (2002) Duodenal Glucose Increases Glucose Fluxes and Lactose Synthesis in Grass-Silage Fed Dairy Cows. Journal of Dairy Science, 85, 595-606. https://doi.org/10.3168/jds.S0022-0302(02)74113-1

[46] Lemosquet, S., Rigout, S., Bach, A., Rulquin, H. and Blum, W. (2004) Glucose Metabolism in Lactating Cows in Response to Isoenergetic Infusions of Propionic Acid or Duodenal Glucose. Journal of Dairy Science, 87, 1767-1777. https://doi.org/10.3168/jds.S0022-0302(04)73332-9

[47] Garcia, S.C. and Fulkerson, W.J. (2005) Opportunities for Future Australian Dairy Systems: A Review. Australian Journal Experimental Agriculture, 45, 1041-1055. https://doi.org/10.1071/EA04143

[48] Dixon, R.M. and Stockdale, C.R. (1999) Associative Effects between Forages and Grains: Consequences for Feed Utilization. Australian Journal of Agricultural Research, 50, 757-773. https://doi.org/10.1071/AR98165

[49] Delahoy, J.E., Muller, L.D., Bargo, F., Cassidy, T.W. and Holden, L.A. (2003) Supplemental Carbohydrate Sources for Lactating Dairy Cows on Pasture. Journal of Dairy Science, 86, 906-915. https://doi.org/10.3168/jds.S0022-0302(03)73673-X

[50] Chilliard, Y., Bocquier, F. and Doreau, M. (1998) Digestive and Metabolic Adaptations of Ruminants to Undernutrition, and Consequences on Reproduction. Reproduction Nutrition Development, 38, 131-152. https://doi.org/10.1051/rnd:19980201

[51] Cissé, M., Chilliard, Y., Coxam, V., Davicco, M.J. and Remond, B. (1991) Slow Release Somatotropin in Dairy Heifers and Cows Fed Two Levels of Energy Concentrate. 2. Plasma Hormones and Metabolites. Journal of Dairy Science, 74, 1382-1394. https://doi.org/10.3168/jds.S0022-0302(91)78293-3

[52] Grummer, R.R. (1995) Impact of Changes in Organic Nutrient Metabolism on Feeding the Transition Dairy Cow. Journal of Animal Science, 73, 2820-2833. https://doi.org/10.2527/1995.7392820x

[53] Van Knegsel, A.T.M., Van den Brand, H., Graat, E.A.M., Dijkstra, J., Jorritsma, R., Decuypere, E., Tamminga, S. and Kemp, B. (2007) Dietary Energy Source in Dairy Cows in Early Lactation: Metabolites and Metabolic Hormones. Journal of Dairy 
Science, 90, 1477-1485. https://doi.org/10.3168/jds.S0022-0302(07)71633-8

[54] McGuire, M.A., Dwyer, D.A., Bauman, D.E. and Smith, D.F. (1998) Insulin-Like Growth Factors in Plasma and Afferent Mammary Lymph of Lactating Cows Deprived of Feed or Treated with Bovine Somatotropin. Journal of Dairy Science, 81, 950-957. https://doi.org/10.3168/jds.S0022-0302(98)75655-3

[55] DePeters, E.J. and Ferguson, J.D. (1992) Nonprotein Nitrogen and Protein Distribution in the Milk of Cows. Journal of Dairy Science, 75, 3192-3209. https://doi.org/10.3168/jds.S0022-0302(92)78085-0

[56] Kolver, E.S. and de Veth, M.J. (2002) Prediction of Ruminal pH from Pasture-Based Diets. Journal of Dairy Science, 85, 1255-1266. https://doi.org/10.3168/jds.S0022-0302(02)74190-8

[57] Dijkstra, J., Boer, H., Van Bruchem, J., Bruining, M. and Tamminga, S. (1993) Absorption of Volatile Fatty Acids from the Rumen of Lactating Dairy Cows as Influenced by Volatile Fatty Acid Concentration, $\mathrm{pH}$ and Rumen Liquid Volume. British Journal of Nutrition, 69, 385-396. https://doi.org/10.1079/BJN19930041

[58] Granzin, B.C. (2004) Effects of Supplement Grain Type and Level of Feeding on the Milk Production of Early-Lactation Holstein-Friesian Cows Grazing Temperate and Tropical Pastures. Australian Journal Experimental Agriculture, 44, 735-743. https://doi.org/10.1071/EA03042

[59] Mould, F.L. and Orskov, E.R. (1983) Manipulation of Rumen Fluid pH and Its Influence on Cellulolysis in Sacco, Dry Matter Degradation and the Rumen Microflora of Sheep Offered Either Hay or Concentrate. Animal Science and Technology, 10, 1-14. https://doi.org/10.1016/0377-8401(83)90002-0

[60] Antonacci, L., Barbera, P., Garciarena, D.A., Cangiano, C.A. and Gagliostro, G.A. (2009) Effect of Supplementation with Increasing Levels of Concentrate on the Productive Response of Grazing Dairy Cows. Revista Argentina de Producción Animal, 29, 210-211.

[61] Araujo, L.E. (2013) Effect of Increasing Levels of Energy Concentrate Consumption on the Productive Response and Ruminal Environment of Grazing Dairy Cows. Master Science Thesis, Facultad de Ciencias Agrarias, Universidad Nacional de Mar de Plata, Argentina.

[62] Freund, R. and Littell, R. (1981) SAS ${ }^{\circ}$ for Linear Models. SAS Institute Inc., Cary, 187-193.

[63] Peyraud, J.L. and Delaby, L. (2001) Ideal Concentrate Feeds for Grazing Dairy Cows Responses to Supplementation in Interaction with Grazing Management and Grass Quality. In: Garnsworthy, P.C. and Wiseman, J., Eds., Recent Advances in Animal Nutrition, Nottingham University Press, Nottingham, 203.

[64] Dillon, P. (2006) Achieving High Dry Matter Intake from Pasture with Grazing Dairy Cows. In: Elgersma, A., Dijkstra, J. and Tamminga, S., Eds., Fresh Herbage for Dairy Cattle: The Key to a Sustainable Food Chain, Springer, Berlin, 1-26. https://doi.org/10.1007/978-1-4020-5452-5_1

[65] Stockdale, C.R. (2000) Levels of Pasture Substitution When Concentrates Are Fed to Grazing Dairy Cows in Northern Victoria. Australian Journal of Experimental Agriculture, 40, 913-921. https://doi.org/10.1071/EA00034 